This is the final peer-reviewed accepted manuscript of: Cicatiello, Clara; FRANCO, SILVIO; Pancino, Barbara; Blasi, Emanuele; Falasconi, Luca, The dark side of retail food waste: Evidences from in-store data, which has been published in final form in RESOURCES CONSERVATION AND RECYCLING 2017 volume 125 pages 273-281. The final published version is available online at: http://dx.doi.org/10.1016/j.resconrec.2017.06.010.

(C) 2017 Elsevier. This manuscript version is made available under the Creative Commons Attribution-NonCommercialNoDerivs (CC BY-NC-ND) 4.0 International License (http://creativecommons.org/licenses/by-nc-nd/4.0/)

\title{
The dark side of retail food waste: Evidences from in-store data
}

\author{
Clara Cicatiello $^{\mathrm{a}}$, Silvio Franco ${ }^{\mathrm{b}}$, Barbara Pancino $^{\mathrm{b}}$, Emanuele Blasi ${ }^{\mathrm{a}}$, Luca Falasconi ${ }^{\mathrm{c}}$ \\ a Department of Innovation in Biological Systems, Food and Forestry, Università degli Studi della Tuscia, via San Camillo de Lellis snc, 01100, Viterbo, Italy ${ }^{\mathbf{b}}$ Department of Economics and \\ Management, Università degli Studi della Tuscia, via del Paradiso 47, 01100, Viterbo, Italy \\ c Department of Agricultural and Food Sciences, Alma Mater Studiorum Università di Bologna, Viale Fanin 50, 40127, Bologna, Italy
}

Keywords:

Food waste

Food surplus

Retail

Supermarket

Unrecorded food waste

Food redistribution

Food waste prevention

\begin{abstract}
A B S T R A C T
This study tackles the quantification of in-store food waste, with a specific focus on the distinction between the edible and inedible fraction. A meta-analysis of the studies dealing with retail food waste quantification is provided to identify the results obtained so far. Then, the mass and value of food waste produced in 2015 at one retail store in Italy is analysed, basing on the store's food waste records and on the reports of a redistribution initiative involving the edible fraction of the food waste produced. In one year, 70.6 tons of food (for a value of nearly $170,000 €$ ) are wasted, mostly bread and fresh fruit and vegetables. The edible fraction accounts for $35 \%$ of the total food waste, mostly from fresh meat and bakery departments. Results also disclose a significant amount of unrecorded food waste, confirming that many gaps exist in the food waste recording procedure at retail stores.
\end{abstract}

\section{Introduction}

Food waste is a major social, nutritional and environmental issue affecting the sustainability of the food chain (Parfitt et al., 2010; Kummu et al., 2012; Abeliotis et al., 2015; Scherhaufer et al., 2015; De Laurentiis et al., 2016). It is caused by climate and biological factors as well as by the behaviours of food chain actors, which are linked to different socio-economic factors (Buzby and Hyman, 2012; AschemannWitzel et al., 2015; Setti et al., 2016; Canali et al., 2016).

Food waste is generated in all stages of the supply chain, with different features and motivations. According to a comprehensive study conducted in 2012, retail food waste is estimated as 4.6 million tons in 2012, i.e. about $5 \%$ of the total food wasted along the supply chain (Stenmarck et al., 2016), much less than the other stages of the supply chain. However, there are several reasons why the study of retail food waste is particularly important (Gruber et al., 2016): (i) retailers have a great influence in shaping both the features of food production and the preferences of consumers; (ii) the absolute quantities of food waste generated at retail stores are very significant with respect to the much more scattered food waste production at other stages of the food chain, e.g. at households; (iii) retail stores are the place where several different food chain actors intersect. Moreover, the public opinion is recently pushing for a greater consideration of the retail food waste issue. Movements against food waste are emerging, asking the food chain actors, particularly those operating at retail stage, for specific interventions to face this phenomenon. In Denmark, the activity of the Stop Wasting Food movement (Stop Spild Af Mad; www. stopspildafmad.dk) led to the adoption by all Danish retailers of a food waste reduction strategy. In France, it is worth mentioning the awareness campaign of Intermarché "Inglorious fruits and vegetables", and the recent regulation that compels all supermarkets with a sales area exceeding $400 \mathrm{~m}^{2}$ to establish agreements with charities with the purpose of donating them the unsold food. ${ }^{1}$ In Italy as well, a law dealing with food waste redistribution initiatives at different stages of the chain has been released in $2016 .^{2}$

Nonetheless, the study of food waste in the retail has long been neglected. In the retail management disciplines, the issue of retail food waste has only been touched in connection with the rate of "shrinkage", which represents the gap between inventories and sales and is commonly used as an indicator of performance of retail stores (Avery et al., 2012; Buzby et al., 2015; Buzby et al., 2016). In other papers, the issue of retail food waste is tackled in connection to food security concerns (Parfitt et al., 2010) or environmental issues linked to waste management as well as resources consumption for food production (Gustavsson 
and Stage, 2011; Beretta et al., 2013). It is only very recently that the literature dealing with the actual quantification of food waste at the retail stage have started flourishing.

The first studies dealing with the quantification of food waste at retail stores have been conducted in Sweden (Gustavsson and Stage, 2011; Eriksson et al., 2012). The interest on retail food waste has rapidly increased as some studies suggested that, contrarily to what happens in other steps of the chain, a significant share of the products considered unsalable by the retailers (e.g. products approaching the expirations date or bearing minor packaging defects) is still perfectly suitable for human consumption. Such products can be re-used, e.g. by redistribution initiatives targeting to the people in need (Segrè et al., 2009; Lebersorger and Schneider, 2014; Cicatiello et al., 2016; Garrone et al., 2014b; Aiello et al., 2014), or offered to customers at a reduced price, with interesting and still under-investigated implications on the amount of food waste produced (Aschemann-Witzel et al., 2015). The incidence of edible items over the total food waste produced in the retail is still unknown, although some redistribution initiatives operating in Italy suggest that it can reach up to 60 tons of food per store each year (Segrè et al., 2009). This means that at the retail stage the real extent of "food waste", i.e. the amount of products discarded from the chain that become unfit for human consumption (Papargyropoulou et al., 2014), may be much lower than expected.

Moving from this state of the art, in this paper we aim to investigate the quantity and quality of food waste in retail stores, with a specific focus on the distinction between the edible and inedible fraction. To this purpose, we first examine, through a meta-analysis, the studies dealing with retail food waste quantification published so far; then, we analyse in-store food waste data retrieved for one year in one Italian outlet.

\section{Meta-analysis of studies on retail food waste quantification}

The generation of food waste in the retail is linked to food stocks management practices as well as to the purchasing behaviour of the customers (Gustavsson et al., 2011; Gunders, 2012). Food items can be discarded due to damaged packaging linked to improper stock management (Parfitt et al., 2010) or to technical malfunctions during the storage (Ziegler and Floros, 2011; Choudhury, 2006). Overstocking linked to the difficulty in predicting the number of products purchased by the customers is also reported as a possible cause of food waste in the retail (Stuart, 2009; Gunders, 2012), although take-back agreements with suppliers may hide part of such waste (Eriksson et al., 2017). Customer behaviours and preferences at the store are a strong driver of food waste generation (Gunders, 2012; Gustavsson et al., 2011; Parfitt et al., 2010; Stuart, 2009): sub-standard products are often rejected by consumers, therefore they are very likely to remain unsold and be wasted; the waste of holyday foods is also very common, as their purchase is concentrated in a limited period. In general, all these behaviours depend on a range of personal and social factors, which may also include the features of the shopping environment, i.e. the experience that the store is able to provide to customers (Cicatiello et al., 2015).

Investigating the extent of food waste in the retail is a complex task, as the way discarded food is registered depends on the retailers' internal organization and on the influences of local policies (Parfitt et al., 2010). With the aim of providing a synthesis of the methodologies and main results of the empirical studies tackling retail food waste quantification, we carried out a meta-analysis of the available papers indexed in Scopus. Namely, we selected all the documents where the keywords "food waste" OR "food loss" appeared in the title, abstract or keywords in combination with "retail" OR "supermarket". Out of 121 resulting documents, only the 86 journal articles were considered. Their abstracts were screened to check whether in each paper an actual quantification of retail food waste was performed, as this is the focus of our research. Table 1 reports the list of the 16 papers selected according to this criteria, as well as the following information for each of them: main focus of the paper, country where the food waste quantification was carried out, type of case study, type and source of data used in the study, food categories concerned, main results on the assessment of retail food waste.

Seven articles refer to studies conducted in Sweden. Indeed, the Nordic countries are those where the knowledge on retail food waste is most developed, also thanks to some reports of projects and national initiatives published in grey literature (e.g. Stenmark et al., 2011; Hanssen and Møller, 2013).

Some of these studies have a very broad objective (e.g. to study the total extent of food waste along the food chain), so that the data reported on retail food waste only represent a minor part of the results. Secondary data at the country level was used in Ju et al. (2017), Buzby and Hyman (2012) and Love et al. (2015), while qualitative data were collected in Mena et al. (2011). Twelve studies involved quantitative data retrieval on food waste at stores (although five of them refer to the same project, developed in Sweden on 6 stores), mostly relying on data collected through the regular waste recording process of the stores. This process, which has a key role in providing data on the extent of food waste at stores, typically entails a daily collection of the unsaleable food items, whose bar code is electronically recorded by the staff, thus generating a database by item.

Among the several product categories analysed in the literature, fruit and vegetables, dairy products, meat and bread show a higher waste. Namely, the waste of bread has an incidence of up to $6-7 \%$ with respect to the quantity delivered by suppliers (Mena et al., 2011; Gustavsson and Stage, 2011; Lebersorger and Schneider, 2014), and represents the largest fraction of the total food waste (Brancoli et al., 2017; Cicatiello et al., 2016), although this data may be biased by the extent of returns to supplier, which are not accounted in the stores' food waste records (Eriksson et al., 2017). For fruit and vegetables, different figures are reported in the literature (3-7\% in Mena et al., 2011; up to $6 \%$, depending on the type of vegetables, in Gustavsson and Stage, 2011; 4.3\% in Eriksson et al., 2012; 8-9\% in Beretta et al., 2013), but most studies do not consider take-back agreements, so these figures may be underestimated (Eriksson et al., 2017).

Eriksson et al. (2014) demonstrated that waste is higher for organic than for conventional products, suggesting that the rate of waste is closely linked to the sales and turnover of the different retail departments. In the few studies where the extent of waste was studied in stores of different dimension, small stores were found to produce more food waste than large stores (Gustavsson and Stage, 2011; Beretta et al., 2013).

Concerning the characteristics of retail food waste and its potential uses, several studies suggest that some of the food discarded at the retail stage may still be fit for human consumption. Indeed, most causes of food waste do not imply that food is no longer edible, e.g. when food items are discarded because they are approaching the expiration date, have little damages on the packaging, or are visually imperfect (Cicatiello et al., 2016). Aschemann-Witzel et al. (2015) refers at these products as "suboptimal". Such items may be reused for human consumption, by sale at a reduced price (Aschemann-Witzel et al., 2015) or redistribution for social purposes (Falasconi et al., 2015; Segrè et al., 2009; Alexander and Smaje, 2008; Cicatiello et al., 2016). This means that only part of the total food products discarded at the retail stage the "food surplus", according to the framework provided by Papargyropoulou et al. (2014) - can be considered a waste, because it becomes unfit for human consumption (Papargyropoulou et al., 2014). 


\begin{tabular}{|c|c|c|c|c|c|c|c|c|}
\hline Article & Focus of the paper & Country & Case study & Type of data on retail & Source of data on retail & Food categories & Retail food waste & Notes \\
\hline $\begin{array}{l}\text { Brancoli et al. } \\
\text { (2017) }\end{array}$ & $\begin{array}{l}\text { Life cycle assessment of } \\
\text { supermarket food waste }\end{array}$ & Sweden & 1 smkt $410 \mathrm{~m}^{2}$ & $\begin{array}{l}\text { Mass of food waste } \\
\text { fractions }\end{array}$ & $\begin{array}{l}\text { Waste records based on bar- } \\
\text { code and manual recording }\end{array}$ & $\begin{array}{l}\text { Bread, vegetables, fruit, } \\
\text { pastry, meat, ready meals, } \\
\text { dairy }\end{array}$ & $\begin{array}{l}22.5 \text { ton per year ( } 30 \% \text { bread, } \\
15 \% \text { vegetables) }\end{array}$ & \\
\hline $\begin{array}{l}\text { Eriksson et al. } \\
\text { (2017) }\end{array}$ & $\begin{array}{l}\text { Role of take-back } \\
\text { agreements in the } \\
\text { generation of food waste }\end{array}$ & Sweden & $\begin{array}{l}6 \text { smkt, same chain, } \\
2300 \text { to } 4900 \text { sqm }\end{array}$ & $\begin{array}{l}\text { Mass of unsold and } \\
\text { returned products }\end{array}$ & $\begin{array}{l}\text { Store waste records; data } \\
\text { from suppliers; interviews }\end{array}$ & $\begin{array}{l}\text { Bread, fruit \& vegetables, } \\
\text { milk }\end{array}$ & $\begin{array}{l}3.6 \% \text { of fruit \& vegetables was } \\
\text { returned; } 1.1 \% \text { wasted in store. } \\
\text { Returns of bread vary among } \\
\text { stores, may be over } 50 \%\end{array}$ & \\
\hline Ju et al. (2017) & $\begin{array}{l}\text { To calculate food loss } \\
\text { rated at the different step } \\
\text { of the food chain }\end{array}$ & Japan & Food supply chain & $\begin{array}{l}\text { Breakdown of } \\
\text { domestic net food } \\
\text { supply for steps of the } \\
\text { food chain }\end{array}$ & $\begin{array}{l}\text { Japanese Food Balance } \\
\text { Sheet; data from Japanese } \\
\text { Ministry of Agriculture }\end{array}$ & All & $\begin{array}{l}\text { Out of total retail food waste, } \\
23 \% \text { is of dairy products, } 15 \% \\
\text { vegetables; } 15 \% \text { grains }\end{array}$ & $\begin{array}{l}\text { Food loss rates only refer to the } \\
\text { edible parts of products. } \\
\text { Inedible parts are estimated } \\
\text { and subtracted. }\end{array}$ \\
\hline $\begin{array}{l}\text { Cicatiello et al. } \\
\text { (2016) }\end{array}$ & $\begin{array}{l}\text { Environmental, social and } \\
\text { economic impact of retail } \\
\text { food waste }\end{array}$ & Italy & 1 smkt $5300 \mathrm{sqm}$ & $\begin{array}{l}\text { Weight and value of } \\
\text { edible fraction of food } \\
\text { waste }\end{array}$ & $\begin{array}{l}\text { Transport records on edible } \\
\text { food waste donated to } \\
\text { charity within a food } \\
\text { redistribution initiative }\end{array}$ & $\begin{array}{l}12 \text { food categories including } \\
\text { fruit, vegetables, bread, } \\
\text { dairy, meat, groceries }\end{array}$ & $\begin{array}{l}23.5 \text { ton }(70 \% \text { bread), } 46,000 € \\
\text { per year, in one smkt }\end{array}$ & $\begin{array}{l}\text { Results are an underestimation } \\
\text { of the total food waste, as they } \\
\text { only concern the edible fraction } \\
\text { donated to a charity }\end{array}$ \\
\hline $\begin{array}{l}\text { Eriksson et al. } \\
\quad(2016)\end{array}$ & $\begin{array}{l}\text { Potential reduction in } \\
\text { food waste with reduced } \\
\text { storage temperature }\end{array}$ & Sweden & $\begin{array}{l}6 \text { smkt, same chain, } \\
2300 \text { to } 4900 \text { sqm }\end{array}$ & $\begin{array}{l}\text { Mass and cost of } \\
\text { unsold food products }\end{array}$ & $\begin{array}{l}\text { Waste records based on bar- } \\
\text { code }\end{array}$ & $\begin{array}{l}\text { Dairy, cheese, deli and meat } \\
\text { departments }\end{array}$ & $\begin{array}{l}16-30 \% \text { food waste reduction } \\
\text { when storage temperature is } \\
\text { decreased to } 2{ }^{\circ} \mathrm{C}\end{array}$ & $\begin{array}{l}\text { The paper only reports\% of } \\
\text { food waste reduction with } \\
\text { decreased storage temperature }\end{array}$ \\
\hline $\begin{array}{l}\text { Scholz et al. } \\
\text { (2015) }\end{array}$ & $\begin{array}{l}\text { GHG emissions linked to } \\
\text { retail food waste }\end{array}$ & Sweden & $\begin{array}{l}6 \text { smkt, same chain, } \\
2300 \text { to } 4900 \text { sqm }\end{array}$ & $\begin{array}{l}\text { Data of food products } \\
\text { sold or wasted at retail } \\
\text { level }\end{array}$ & $\begin{array}{l}\text { Waste records based on bar- } \\
\text { code }\end{array}$ & $\begin{array}{l}\text { Meat, deli, cheese, dairy and } \\
\text { fruit \& vegetable } \\
\text { departments }\end{array}$ & $\begin{array}{l}1570 \text { ton in } 3 \text { years, in } 6 \mathrm{smkt} \text {, } \\
\text { corresponding to } 2500 \text { ton } \mathrm{CO}_{2} \mathrm{e}\end{array}$ & \\
\hline $\begin{array}{l}\text { Buzby et al. } \\
\text { (2015) }\end{array}$ & $\begin{array}{l}\text { Estimate of food losses of } \\
\text { US supermarkets basing } \\
\text { on shrink data }\end{array}$ & USA & $\begin{array}{l}2900 \text { stores } \\
\text { belonging to } 5 \text { chains }\end{array}$ & $\begin{array}{l}\text { Weekly shipment and } \\
\text { sales of each food item }\end{array}$ & $\begin{array}{l}\text { Data on Nielsen Perishables } \\
\text { Group }\end{array}$ & $\begin{array}{l}24 \text { fresh fruits and } 31 \text { fresh } \\
\text { vegetables }\end{array}$ & $\begin{array}{l}\text { Average shrinks } 12-13 \% \text { of fresh } \\
\text { fruits; } 11 \% \text { of fresh vegetables }\end{array}$ & - \\
\hline $\begin{array}{l}\text { Love et al. } \\
\text { (2015) }\end{array}$ & $\begin{array}{l}\text { Estimate seafood losses } \\
\text { along the supply chain }\end{array}$ & USA & $\begin{array}{l}\text { National seafood } \\
\text { supply chain }\end{array}$ & $\begin{array}{l}\text { 5-year data on seafood } \\
\text { supply and loss }\end{array}$ & $\begin{array}{l}\text { Review of national and } \\
\text { international reports }\end{array}$ & $\begin{array}{l}\text { Fresh and frozen, canned, } \\
\text { cured seafood }\end{array}$ & $\begin{array}{l}0.15 \text { million metric tons of } \\
\text { seafood in } 5 \text { years }\end{array}$ & $\begin{array}{l}\text { The study does not provide } \\
\text { more specific data for the retail } \\
\text { stage of the supply chain }\end{array}$ \\
\hline $\begin{array}{l}\text { Eriksson et al. } \\
\quad \text { (2014) }\end{array}$ & $\begin{array}{l}\text { Waste of organic vs. } \\
\text { conventional animal } \\
\text { products }\end{array}$ & Sweden & $\begin{array}{l}6 \text { smkt, same chain, } \\
2300 \text { to } 4900 \text { sqm }\end{array}$ & $\begin{array}{l}\text { Pre-store (rejections) } \\
\text { and in-store food } \\
\text { waste }\end{array}$ & $\begin{array}{l}\text { Waste records based on bar- } \\
\text { code }\end{array}$ & $\begin{array}{l}\text { Fresh meat, deli, dairy and } \\
\text { cheese departments }\end{array}$ & $\begin{array}{l}\text { Average waste } 0.56 \% \text { for } \\
\text { conventional and } 0.70 \% \text { for } \\
\text { organic products }\end{array}$ & \\
\hline $\begin{array}{l}\text { Lanfranchi et al. } \\
\quad(2014)\end{array}$ & $\begin{array}{l}\text { To investigate the extent } \\
\text { of retail food waste and to } \\
\text { propose corrective } \\
\text { actions }\end{array}$ & Italy & $13 \mathrm{smkt}$ & $\begin{array}{l}\text { 5-year data on sales, } \\
\text { broken down by } \\
\text { department }\end{array}$ & Sales records & $\begin{array}{l}7 \text { dept. including } \\
\text { fruit \& vegetables, dairy, } \\
\text { meat, frozen foods }\end{array}$ & $\begin{array}{l}0.31-0.52 \% \text { incidence of food } \\
\text { waste on turnover }\end{array}$ & $\begin{array}{l}\text { The paper also reports the } \\
\text { absolute values (kg) of waste } \\
\text { for some dept., but no total }\end{array}$ \\
\hline $\begin{array}{l}\text { Lebersorger and } \\
\text { Schnei-der } \\
(2014)\end{array}$ & $\begin{array}{l}\text { To quantify food loss } \\
\text { rates in the retail and } \\
\text { analyse reasons }\end{array}$ & Austria & 612 retail outlets & $\begin{array}{l}\text { 3-year data on food } \\
\text { waste records }\end{array}$ & $\begin{array}{l}\text { Waste records provided by } \\
\text { one retailer }\end{array}$ & $\begin{array}{l}\text { Fruit \& vegetables, } \\
\text { bread \& pastry, dairy } \\
\text { products }\end{array}$ & $\begin{array}{l}\text { Food loss rates (with respect to } \\
\text { sales): } 1.14 \% \text { for dairy products, } \\
3.99 \% \text { for bread \& pastry, } 4.19 \% \\
\text { for fruit \& vegetables }\end{array}$ & \\
\hline $\begin{array}{l}\text { Beretta et al. } \\
\quad(2013)\end{array}$ & $\begin{array}{l}\text { To quantify food loss in } \\
\text { Switzerland across the } \\
\text { entire food value chain }\end{array}$ & $\begin{array}{l}\text { Switzer- } \\
\text { land }\end{array}$ & $\begin{array}{l}3 \text { smkt chains, } 1 \\
\text { logistic centre, } 5 \\
\text { bakeries }\end{array}$ & $\begin{array}{l}\text { Quota of food loss as } \\
\text { declared by retailers }\end{array}$ & $\begin{array}{l}\text { Data provided by the } \\
\text { retailers }\end{array}$ & $\begin{array}{l}22 \text { food categories including } \\
\text { fruit \& vegetables, cereals, } \\
\text { dairy, meat, fish }\end{array}$ & $\begin{array}{l}\text { Average } 2.2 \% \text { losses, higher in } \\
\text { small shops, for rare and } \\
\text { perishable products }\end{array}$ & \\
\hline $\begin{array}{l}\text { Buzby and } \\
\text { Hyman } \\
(2012)\end{array}$ & $\begin{array}{l}\text { Extent of food loss and } \\
\text { waste in developed } \\
\text { countries }\end{array}$ & USA & Whole country & $\begin{array}{l}\text { Loss estimates for each } \\
\text { single food products, } \\
\text { compared with retail } \\
\text { sales }\end{array}$ & $\begin{array}{l}\text { Loss-Adjusted Food } \\
\text { Availability data for loss } \\
\text { estimates; retail sales to } \\
\text { evaluate food consumption }\end{array}$ & $\begin{array}{l}200 \text { individual food } \\
\text { products }\end{array}$ & $\begin{array}{l}47,000 \text { million } \$ \text {, accounting for } \\
9 \% \text { of total losses, mostly } \\
\text { vegetables, dairy products, meat }\end{array}$ & \\
\hline $\begin{array}{l}\text { Eriksson et al. } \\
\qquad(2012)\end{array}$ & $\begin{array}{l}\text { Analysis of fresh fruit and } \\
\text { vegetables flows, } \\
\text { including food waste }\end{array}$ & Sweden & $\begin{array}{l}6 \text { smkt, same chain, } \\
2300-4900 \text { sqm }\end{array}$ & $\begin{array}{l}\text { Mass data on pre-store } \\
\text { and in-store food } \\
\text { waste, unrecorded } \\
\text { food waste and total } \\
\text { sales }\end{array}$ & $\begin{array}{l}\text { Waste records based on bar- } \\
\text { code; } 2 \text { weeks test to detect } \\
\text { unrecorded food waste; data } \\
\text { on sales mass }\end{array}$ & Fruit and vegetables & $\begin{array}{l}4.3 \% \text { of food delivered by the } \\
\text { supplier, mostly } \\
\text { fruit \& vegetables }\end{array}$ & - \\
\hline $\begin{array}{l}\text { Gustavsson and } \\
\text { Stage, } \\
(2011)\end{array}$ & $\begin{array}{l}\text { To study store-level waste } \\
\text { of horticultural products }\end{array}$ & Sweden & $\begin{array}{l}9 \text { retail stores of the } \\
\text { same chain }\end{array}$ & $\begin{array}{l}\text { Annual quantities of } \\
\text { waste and sales for } \\
\text { each type of food item } \\
\text { included in the study }\end{array}$ & $\begin{array}{l}\text { Survey questionnaire to store } \\
\text { managers, who based their } \\
\text { answers on the data } \\
\text { retrieved in the daily }\end{array}$ & Fruit and vegetables & $\begin{array}{l}0.42 \%-6.25 \% \text { of waste, } \\
\text { depending on type of product; } \\
\text { waste is higher in small stores }\end{array}$ & - \\
\hline
\end{tabular}


Table 2

Timing of products discard according their best-before and use-by date.

\begin{tabular}{lll}
\hline Type of product & Shelf life $^{\mathrm{a}}$ & Timing of product discard $^{\mathrm{b}}$ \\
\hline Fresh milk & 6 days & 2 days \\
Yogurt & 3 weeks & 3 days \\
Eggs & 4 weeks & 6 days \\
Würstel & $1-2$ months & 3 days \\
Butter & 2 months & 3 days \\
Soft cheese & 2 months & 3 days \\
\hline
\end{tabular}

a Approximate shelf life period from production to expiration date.

$\mathrm{b}$ Before expiration date, according to the procedure applied at the case study store.

\section{Methodology: analysing in-store food waste data}

In this study we analysed the food waste stream of one retail store in Italy, belonging to a major Italian retailer. The store is one of the 378 Italian hypermarkets (sales area $>4500 \mathrm{~m}^{2}$ ); this channel currently represents about $15 \%$ of total food purchases in retail stores, with 12 billion $€$ of sales volume ${ }^{3}$ (Federdistribuzione, 2015).

Within the store, we focused on the food departments, which covered about $55 \%$ of the total sales area. Data on the waste produced by these departments was collected during the year 2015 by the store's staff following the usual waste recording routine, which was established several years before the study period. Every morning the staff screened the shelves and withdrew all the products that had passed or were close to their "best-before" or "use-by" date. Table 2 resumes the schedule followed by the staff to remove from the shelves the products with shorter shelf life, with respect to the indicated expiration date.

Products assumed by the staff to be unsaleable for other reasons, e.g. damaged packaging or blemished fruit and vegetables, were also removed from the shelves. The bar-code of the culled products was then recorded with a scanner before discarding. It should be noted that, despite this study was based on the analysis of a single retail store, the food waste recording process, as well as the schedule of discard of products approaching best-before and use-by dates, is a standard procedure of the over 1000 stores managed by the same retailer.

The information recorded during the daily process of products removal from the shelves made up a comprehensive database, where, for each item discarded at least once along the year, the following information were reported:

- store department (11 departments);

- food group;

- code of the item;

- brief description of the item;

- quantity discarded along the year (number of items for packaged products, kilograms for unpacked products);

- retail cost associated with the quantity discarded (calculated as the multiplication between the unit cost and the quantity).

For all packed items, the net weight was deduced from the description and noted in a further column. This allowed to conduct elaborations on the mass of the food waste.

In accordance with Eriksson et al. (2012), this waste was defined as "recorded in-store waste".

At the time of the data collection, the same store was involved in a food redistribution initiative, established several years before the study, in partnership with a local charity. Data on the food collected for redistribution was also gathered during the study period. The redistribution process was daily based: every morning, during the regular

\footnotetext{
${ }^{3}$ In Italy, out of 115.2 billion $€$ of total sales volume, the market share of modern retail channels (hypermarkets, supermarkets, small retail stores, discount) is $73.1 \%$. The remaining $26.9 \%$ of food sales is shared among traditional grocery stores and street vendors (Federdistribuzione, 2015).
} 


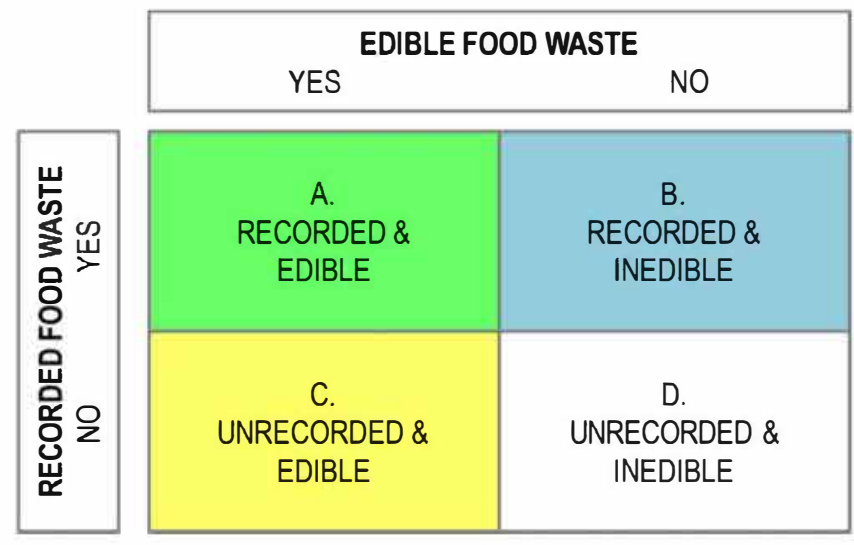

Fig. 1. Categories of food waste concerned by this study.

Source: authors' elaboration

food waste recording routine, the edible food items were isolated from the rest of the culled products, recorded as donations and then picked up by volunteers of the charity. The data retrieval on the redistribution process resulted in a second database, organized just as the first one, except that the records referred to the items donated. The items recorded in the second database constitute what we defined the "edible food waste". Indeed, before picking up the food donated, the volunteers of the charity were in charge of verifying that all the items donated were perfectly fit for human consumption; only those deemed edible were then picked up and recorded as donations. The remaining items, that we called "inedible food waste", correspond to the food waste disposed by the store.

In total, the database on recorded in-store food waste counted 10,662 items, whilst 1688 items were reported in the database focused on edible items.

Fig. 1 provides an overview of the data considered in this study. Being A + B + C + D the total food waste generated in the store (referred as "food surplus" in Papargyropoulou et al., 2014), through the database of "recorded in-store waste" we gathered data on the A + B fraction, while the records on donations provided an assessment on all edible items discarded from the store, marked as A + C in the figure. By crossing these information, we were able to recognize the mass and value of products falling under A, B and C food waste categories, for each department of the store.

Namely, many edible items were recorded both in the first and in the second database: the first record occurred when they were considered unsaleable and thus removed from the shelf, the second when they were deemed edible and thus donated for the sake of the redistribution initiative. The overlapping among these two information therefore allowed to calculate the incidence of edible items on the recorded food waste, therefore assessing the extent of the A section in

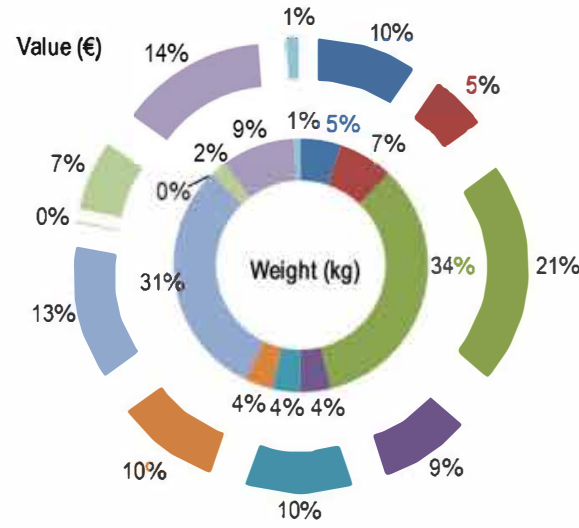

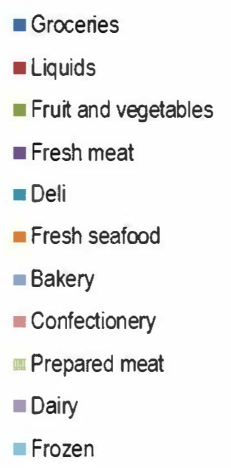

Fig. 2. Value and weight of food waste by store department (year 2015). Source: authors' elaboration
Fig. 1. However, part of the items recorded as edible were not found in the in-store waste records; that is, some items were actually removed from sale without recording. This is because, as Eriksson et al. (2012) pointed out, the food waste recording routine may show gaps, especially in the departments offering unpacked products. Such items, discarded without being recorded as waste, are commonly referred as "unrecorded in-store waste" (C + D in Fig. 1). Comparing the two databases used in this study, we detected some donated (thus edible) items that had not been previously recorded as food waste. Therefore, we were able to assess the quantity and value of the unrecorded food waste fraction which was still fit for human consumption (section $C$ in Fig. 1). Instead, we could not gather any information about unrecorded items which were no longer fit for human consumption, thus not being suitable for donation (1).

\section{Results}

The food waste recorded at the store in the year 2015 accounted for 49 tons, corresponding to about $148,000 €$ in value. ${ }^{4}$ Additional 21.6 tons of unrecorded food waste were detected through the analysis of the data on the edible food collected for redistribution. The total in-store waste concerned by this study was thus of 70.6 tons, for a value of nearly $170,000 €$.

In terms of weight, fruit and vegetables together with bakery products represented about two-thirds of the total food wasted (Fig. 2). The share of food waste value among the store departments was much more balanced, as the most wasted products were often those of lower value. Dairy products and groceries, despite the limited weight of the products discarded, represented a large quota of the value of the food waste.

The waste of fresh seafood was also found to be a huge cost for the store, especially compared with the very limited quantity discarded. On the contrary, most of the waste produced in the bakery department was made up of bread baked at the store; as the retail cost of this type of product was very low, the huge quantity wasted only accounted for the $13 \%$ of the total value of waste. It should be noted that the bakery department was the one where the highest quantity of unrecorded food waste was detected, namely concerning bread and pizza baked at the store. These items were usually not recorded as waste due to the accounting system of the store which considered them a discard of raw materials rather than of finished products.

Looking at the data of the redistribution initiative, 24.6 tons of food waste were collected and reused for human consumption. Therefore, despite being no longer acceptable to the market, these products had neither lost their function nor their nutritional value.

Table 3 reports the extent of edible food recorded in each department in terms of mass, together with the correspondent data on total food waste (recorded + unrecorded).

The grocery department included packed pasta and rice, biscuits and other industrial bakery products. Liquids mainly referred to canned products, such as tomato sauce, canned vegetables, tuna and so on. In these two departments, the quantity of food waste produced was quite low with respect to other departments, and the incidence of the edible fraction was negligible. Instead, in the fruit and vegetables department, despite the waste was very relevant $-65 \mathrm{~kg}$ per day on average - the rate of redistribution was very low, as only $114 \mathrm{~kg}$ of fruit and vegetables were donated in 2015.

In the fresh meat department, packed products were deemed unsaleable two days before the use-by date, following the standard procedure of discard applied at the store. This helped to reach a high rate of redistribution, very close to $100 \%$. This was instead not the case of other refrigerated items, such as those on sale at the prepared meat and dairy departments. In these departments, although the same timing of

\footnotetext{
${ }^{4}$ The value of the food waste is calculated as the sum of the retail cost of the culled food items. Therefore, the market value of the same products is higher than this figure.
} 
Table 3

Extent of edible food by department (data in $\mathrm{kg}$ ) and occurrence.

\begin{tabular}{lll}
\hline Department & Food waste & $\begin{array}{l}\text { Redistributed edible } \\
\text { fraction }\end{array}$ \\
\hline Groceries & & $\begin{array}{l}\text { Occurrence of edible } \\
\text { fraction }\end{array}$ \\
Liquids & 3667 & 164 \\
Fruit and & 4912 & 0 \\
$\quad$ vegetables & 24,035 & 114 \\
Fresh meat & & \\
Deli & 2771 & 2758 \\
Fresh seafood & 2475 & 0 \\
Bakery & 2493 & 2 \\
Confectionery & 21,599 & 21,511 \\
Prepared meat & 81 & 59 \\
Dairy & 1367 & 8 \\
Frozen & 6627 & 21 \\
TOTAL & 583 & 3 \\
\hline
\end{tabular}

Table 4

Value of waste and edible fraction by store department.

\begin{tabular}{llll}
\hline Department & Waste & $\begin{array}{l}\text { Redistributed edible } \\
\text { fraction }\end{array}$ & $\begin{array}{l}\text { Incidence of edible } \\
\text { fraction }\end{array}$ \\
\hline Groceries & $€ 16,287$ & $€ 1144$ & $7,0 \%$ \\
Liquids & $€ 9032$ & $€ 2$ & $0,0 \%$ \\
Fruit and vegetables & $€ 36,372$ & $€ 101$ & $0,3 \%$ \\
Fresh meat & $€ 14,740$ & $€ 14,652$ & $99,4 \%$ \\
Deli & $€ 17,413$ & $€ 30$ \\
Fresh seafood & $€ 16,770$ & $€ 21,511$ & $0,2 \%$ \\
Bakery & $€ 21,854$ & $€ 59$ & $98,4 \%$ \\
Confectionery & $€ 197$ & $30,0 \%$ \\
Prepared meat & $€ 11,466$ & $0,5 \%$ \\
Dairy & $€ 23,736$ & $€ 60$ & $0,3 \%$ \\
Frozen & $€ 2027$ & $€ 11$ & $0,5 \%$ \\
TOTAL & $€ 169,893$ & $€ 37,644$ & $22.2 \%$ \\
\hline
\end{tabular}

discard applied, the collection of edible items concerned a tiny fraction of the whole waste.

It was already mentioned that most of the waste of the bakery and confectionery departments had not been recorded as waste, although collected for redistribution purposes. Besides the accounting issues causing this misalignment of data, it emerged very clearly that in this departments nearly all the waste was still fit for human consumption.

The very low rates of edible products in the deli and frozen departments were largely expected. For what concerns the deli, most of waste is generated from the trimming of prepared meat and cheese served by the weight, or form leftovers too little to be sold, i.e. scraps that cannot be considered edible.

In terms of weight, $35 \%$ of the total food waste was redistributed. This food was thus perfectly edible and it could easily be reused for human consumption. In terms of mass, the extent of the disposed food waste was reduced by one-third in one year as a consequence of the activation of the redistribution initiative. In economic terms, the redistribution allowed to save $22.2 \%$ of food waste value (Table 4), mainly in the fresh meat and bakery departments. With the exception of fresh meat, the incidence of the edible fraction of waste was higher in weight than in value. Namely, the edible fraction of food waste from the bakery department represented more than a half of the total value of edible food waste. Such saving of money, however, had no impact on the business of the store, as the items were actually donated free of charge for redistribution purposes.

\section{Discussion}

Results on the amount of in-store food waste broken down by department were somehow consistent with previous literature (Brancoli et al., 2017; Eriksson et al., 2012; Cicatiello et al., 2016; Beretta et al., 2013), where fruit and vegetables are usually accounted as the largest quota of food waste, representing between $60 \%$ and $70 \%$ of the total weight and about $20 \%$ of the total value of discarded products $(34 \%$ and $21 \%$, respectively, in our study).

For what concerns the dairy products, which are sometimes reported among the items with the highest rate of waste (Lebersorger and Schneider, 2014), it should be noted that many culled dairy products were not reported in the store's records because their discard was treated through take-back agreements with suppliers; in this case, the waste of these foods was realized anyway, but moving it back to another step of the food supply chain (Eriksson et al., 2017).

In the grocery and liquids departments, the generation of waste was mainly due to packaging defects (e.g. packaging misshapen or broken, soiling due to breaking or incorrect handling of products) and, more rarely, to the approaching of the best-before date. This is the reason why most of the products discarded in these departments were unfit for human consumption.

Results for the fruit and vegetables department showed a notable amount of waste. The main reason why these products were discarded was the decay which made them no longer acceptable for consumers (Loebnitz et al., 2015). Such suboptimal products were often considered 


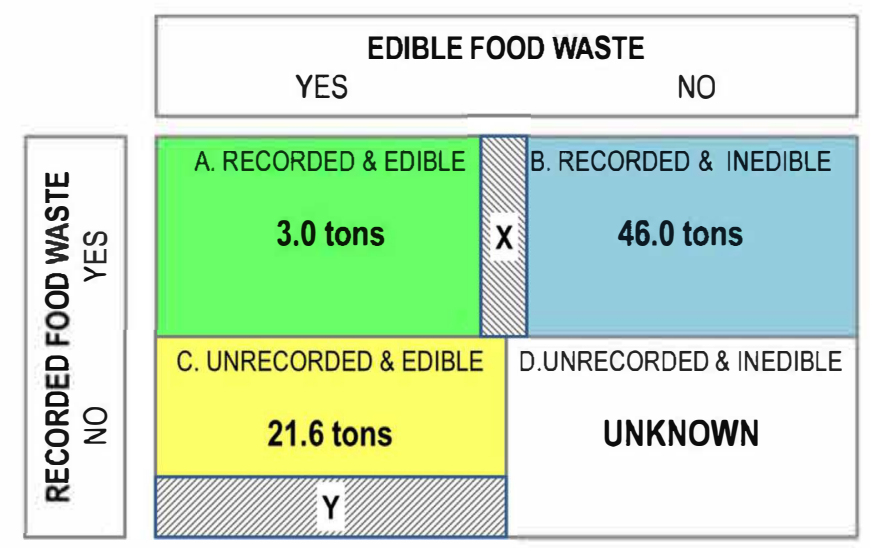

Fig. 3. Overall results by food waste category.

Source: authors' elaboration

not acceptable for redistribution neither: although part of them were probably still edible, there were significant safety concerns from the beneficiaries; therefore, only $114 \mathrm{~kg}$ of fruit and vegetables were donated in 2015.

The difference in redistribution rates between fresh meat products and other refrigerated items (e.g. prepared meat and dairy products) may be explained with a different level of attention by the store's staff in the selection of edible products for redistribution. This suggests that the quota of edible items could be underestimated in prepared meat and dairy departments, as some edible products (e.g. discarded two days before the use-by date) may have not been recorded as such in the data provided by the store management.

Nearly all the waste form the bakery and confectionery departments was still fit for human consumption. This result may be explained with the quality standards required by the customers, who expected to find, at any time of the day, freshly baked products. Another reason may be linked to the low cost of these products - processed and baked at the store - for the store management, compared to similar products delivered by suppliers, which makes more "acceptable" their waste for the store's management.

Therefore, the redistribution was concentrated in the departments of fresh meat and bakery, where the discard of food items was, in most cases, not linked to alteration of the products themselves. Where this was the case, e.g. in the fruit and vegetables department, the incidence of edible items in food waste was very low.

Results show that the edible fraction of this store's food waste accounted for $35 \%$ of the total mass. In the redistribution practice, although the store's staff was responsible for the selection of the items to be redistributed, it was a duty of the collectors to check the quality of the food they were about to pick up; as it can be imagined, they were likely to be very demanding about safety and quality issues, in order to avoid hauling food that could possibly be disregarded by the final users or unsuitable for their needs. As a consequence, some edible food selected for redistribution by the store's staff could have been refused by the collectors, and therefore not recorded as "edible". It follows that the figures of edible food records we presented might be slightly underestimated, the edible fraction being "at least" $35 \%$.

Through the redistribution initiative, the nutritional value of the donated items was recovered, by making them available for the people in need. An ethical function was also accomplished: bread is an icon of the Italian culture as well as an evocative symbol of the food needed for survival; meat is a main protein source and its consumption is commonly considered as a sign of opulence. Limiting the waste of these types of food is therefore an ethical issue, besides being a business imperative. However, redistribution initiatives are not able to reduce retailers' economic loss linked to food waste disposal. Our results showed that the value of the edible fraction of food waste was not negligible, especially if compared to the profit margins of retail businesses, which are typically very low; estimates by the Food Marketing Institute report $1.7 \%$ of net profit after taxes for US supermarkets in 2015 (www.fmi.org). However, some studies suggest that a careful management of redistribution practices may produce economic savings for retailers (Aiello et al., 2014).

To this respect, it is interesting to note that, in this store, no reduced pricing strategies for suboptimal foods was implemented. Some studies to this regard suggest that selling the food items at a reduced price when they are approaching the expiration date may help retailers to find a compromise between satisfying consumers' desire of an optimal price-quality relation and reducing food waste (Aschemann-Witzel et al., 2015). However, the implications of these strategies on overpurchasing, and therefore on the extent of household food waste, are still underexplored (Aschemann-Witzel et al., 2017).

Fig. 3 recaps the overall results with respect to the food waste categories defined in the methodology (see Fig. 1).

The 70.6 tons of food waste reported in the store data were divided among the three food waste categories concerned by this study. In general, the extent of unrecorded food waste was higher than expected, the edible fraction of unrecorded food waste alone accounting for $30 \%$ of the total food waste. Unrecording especially occurred in the bakery department, where less than $1 \%$ of the wasted bread was recorded. We may attempt a comparison with Eriksson et al. (2012), where figures of unrecorded food waste were reported for fruit and vegetables in six Swedish retail outlets: $0.3 \%$ of deliveries was wasted without recording, against $0.99 \%$ which was wasted with recording; therefore, in Eriksson et al. (2012) unrecorded food waste was estimated as a $+30 \%$ over recorded food waste. In this study, this ratio was quite higher, as the detected unrecorded food waste represented a $+44 \%$ over the recorded quantity of food waste. This suggests that a thorough recording of waste is necessary to gather reliable data, especially in the departments dealing with fresh products, which are more likely to remain unrecorded. It should also be noted that, if unrecorded food waste was taken into account, the contribution of retailers to the generation of the total food waste along the chain, which is now estimated in $5 \%$ (Stenmarck et al., 2016), may be reconsidered.

The grey areas in Fig. 3 (named $\mathrm{X}$ and $\mathrm{Y}$ respectively) represent possible bias in the results herein discussed. $\mathrm{X}$ refers to edible items in recorded food waste that might have not been registered as such because of refusal by the collectors in charge of picking up the products of the redistribution initiative, or due to inefficiencies in the separation of edible and inedible items by the store staff. However, since the redistribution routine was well established at the store at the time of data collection, we may assume this bias to be very low. A possibly more 
significant error in the data presented ( $\mathrm{Y}$ in Fig. 3) refers to the existence of more edible items in unrecorded food waste, which were not tracked in the data. This might have been due to difficulties in the collection of edible products in some store departments. Just to make an example, in the deli department, most of the ready-to-eat foods cooked at the store and unsold at the end of the day were not collected for redistribution nor recorded as food waste.

In evaluating the findings of the study, the limitations of the analysis should be kept in mind. First, the results are likely to be strongly influenced by the features of the store selected in the case study, namely the supply management practices and the marketing strategies. However, in large retailers the stock managing practices are well standardized, therefore it can be assumed that the evidences of this study can be carefully generalized. Second, the food waste data recorded may be slightly biased as a consequence of possible missing data and/or unrecorded food waste which was not detected (Eriksson et al., 2012).

\section{Conclusions}

Unlike most of the other stakeholders of the food chain, retailers are likely to be very keen to implement actions aimed at reducing food waste, as it represents a loss in their business, and a risk for their already very narrow - margins. Moreover, previous studies support the assumption that a significant part of retail food waste may still be suitable for human consumption, therefore having a higher degree of "recoverability" (Garrone et al., 2014a) with respect to other stages of the supply chain.

In this study we analysed two complementary sets of detailed food waste records provided by one large retail store in Italy. We investigated the quantity and value of different fractions of the store's food waste, broken down by department. Namely, we were able to assess the quota of edible food waste with respect to the inedible fraction, as well as to detect relevant amounts of wasted products which had not been recorded.

Results disclosed that during one year 70.6 tons of food (nearly $170,000 €$ in terms of value) were wasted, out of which only 49.0 tons were recorded. Consistently with previous studies dealing with retail food waste quantification, most of food waste was represented by bakery products and fresh fruit and vegetables. Out of the total food waste, we found that nearly 25 tons of food were still perfectly suit for human consumption, and could therefore be collected and donated for human consumption purposes. This means that at least $35 \%$ of the total food waste produced at the store did not lose its original function and could be actually saved from wasting. The extent of the edible fraction was particularly relevant in the fresh meat and bakery departments, where the discard of products was typically not linked to deterioration, rather it was a consequence of the standard procedure of products handling with respect to expiration dates. This procedure is largely shared by retail stores, and can be considered non-specific for the store analysed.

Results also showed a very significant amount of unrecorded food waste, confirming the intuition of Eriksson et al. (2012) that significant gaps exist in the food waste recording procedure at retail stores, and that they are likely to be more frequent for fresh products.

The evidences provided by this study suggest that a comprehensive strategy against food waste at the store level may develop along two trajectories. On the one hand, the internal management of the offer may be revised in order to reduce to any possible extent the quantity of food discarded, and the consequent business loss. This can be very relevant, as we have seen, for goods produced within the store, e.g. bread and freshly baked products. Reduced price strategies for products approaching the expiration date may be considered to this respect, although the claim associated with such offers, as well as the effect of these strategies on the total extent of food waste along the supply chain (especially at households) should be further investigated (Aschemann-
Witzel et al., 2017). On the other hand, retailers should be aware that much of the food waste produced at store is still edible. Setting strategies to allow its reuse for human consumption purposes appears to be, besides an ethical concern, a huge opportunity to improve their image in front of consumers, under a Corporate Social Responsibility perspective (Garrone et al., 2014b). Indeed, environmental savings as well as social benefits for the community can be produced when redistribution initiatives are put in place (Eriksson and Spångberg, 2017; Eriksson et al., 2015; Cicatiello et al., 2016). However, even when redistribution practices are implemented, there are no direct economic savings for retailers, although significant economic benefits for the charities involved can be accounted.

Many questions remain unanswered in the study of retail food waste dynamics. With respect to the issues raised by this study, the main topics of prospective research may be outlined as follows: (i) quantifying unrecorded food waste in a larger sample of stores, as its extent may be very significant with respect to the amount of retail food waste currently considered for national and global estimates; (ii) studying the underpinning causes of food waste at stores in relation to different products management practices, following Eriksson et al. (2017); (iii) assessing the effectiveness of strategies against food waste, in terms of benefits for the retailers and/or for the community as a whole.

\section{Acknowledgements}

This research is a part of the project REDUCE, funded by the Italian Ministry of the Environment [RINDEC-2015-0000088] and coordinated by Alma Mater Studiorum University of Bologna. The general aim of the project is to contribute to reducing food waste at the national level, by quantifying food waste in Italy and proposing preventive measures to reduce food waste at different stages of the food chain.

\section{References}

Abeliotis, K., Lasaridi, K., Costarelli, V., Chroni, C., 2015. The implications of food waste generation on climate change: the case of Greece. Sustainable Prod. Consum. 3, 8-14. Aiello, G., Enea, M., Muriana, C., 2014. Economic benefits from food recovery at the retail stage: an application to Italian food chains. Waste Manage. 34 (7), 1306-1316.

Alexander, C., Smaje, C., 2008. Surplus retail food redistribution: an analysis of a third sector model. Resour. Conserv. Recycl. 52 (11), 1290-1298.

Aschemann-Witzel, J., de Hooge, I., Amani, P., Bech-Larsen, T., Oostindjer, M., 2015. Consumer-related food waste: causes and potential for action. Sustainability 7 (6), 6457-6477.

Aschemann-Witzel, J., Jensen, J.H., Jensen, M.H., Kulikovskaja, V., 2017. Consumer behaviour towards price-reduced suboptimal foods in the supermarket and the relation to food waste in households. Appetite 116, 246-258. http://dx.doi.org/10. 1016/j.appet.2017.05.013.

Avery, D.R., Mckay, P.F., Hunter, E.M., 2012. Demography and disappearing merchandise: how older workforces influence retail shrinkage. J. Organ. Behav. 33 (1), $105-120$.

Beretta, C., Stoessel, F., Baier, U., Hellweg, S., 2013. Quantifying food losses and the potential for reduction in Switzerland. Waste Manage. 33 (3), 764-773.

Brancoli, P., Rousta, K., Bolton, K., 2017. Life cycle assessment of supermarket food waste. Resources. Conserv. Recycl. 118, 39-46.

Buzby, J.C., Hyman, J., 2012. Total and per capita value of food loss in the United States. Food Policy 37 (5), 561-570.

Buzby, J.C., Bentley, J.T., Padera, B., Ammon, C., Campuzano, J., 2015. Estimated fresh produce shrink and food loss in US supermarkets. Agriculture 5 (3), 626-648.

Buzby, J.C., Bentley, J.T., Padera, B., Ammon, C., Campuzano Ammon, J.C., 2016. Updated supermarket shrink estimates for fresh foods and their implications for ERS loss-Adjusted food availability data. Economic Information Bulletin Number 155. pp. b155. https://www.ers.usda.gov/webdocs/publications/ei/59692_eib 155.pdf.

Canali, M., Amani, P., Aramyan, L., Gheoldus, M., Moates, G., Östergren, K., Silvennoinen, K., Waldron, K., Vittuari, M., 2016. Food waste drivers in europe, from identification to possible interventions. Sustainability 9 (1), 37.

Choudhury, M.L., 2006. Recent Developments in Reducing Postharvest Losses in the AsiaPacific Region. From: Postharvest Management of Fruit and Vegetables in the AsiaPacific Region. APO.

Cicatiello, C., Pancino, B., Pascucci, S., Franco, S., 2015. Relationship patterns in food purchase: observing social interactions in different shopping environments. J. Agric. Environ. Ethics 28, 21-42.

Cicatiello, C., Franco, S., Pancino, B., Blasi, E., 2016. The value of food waste: an exploratory study on retailing. J. Retail. Consum. Serv. 30, 96-104.

De Laurentiis, V., Hunt, D.V., Rogers, C.D., 2016. Overcoming food security challenges within an Energy/Water/Food nexus (EWFN) approach. Sustainability 8, 95. 
Eriksson, M., Spångberg, J., 2017. Carbon footprint and energy use of food waste management options for fresh fruit and vegetables from supermarkets. Waste Manage.

Eriksson, M., Strid, I., Hansson, P.A., 2012. Food losses in six Swedish retail stores: wastage of fruit and vegetables in relation to quantities delivered. Resour. Conserv. Recycl. 68, 14-20.

Eriksson, M., Strid, I., Hansson, P.A., 2014. Waste of organic and conventional meat and dairy products-A case study from Swedish retail. Resources. Conserv. Recycl. 83, 44-52.

Eriksson, M., Strid, I., Hansson, P.A., 2015. Carbon footprint of food waste management options in the waste hierarchy-a Swedish case study. J. Clean. Prod. 93, 115-125.

Eriksson, M., Strid, I., Hansson, P.A., 2016. Food waste reduction in supermarkets-Ne costs and benefits of reduced storage temperature. Resour. Conserv. Recycl. 107, 73-81.

Eriksson, M., Ghosh, R., Mattsson, L., Ismatov, A., 2017. Take-back agreements in the perspective of food waste generation at the supplier-retailer interface. Resour. Conserv. Recycl. 122, 83-93.

Falasconi, L., Vittuari, M., Politano, A., Segrè, A., 2015. Food waste in school catering: an italian case study. Sustainability 7 (11), 14745-14760.

Federdistribuzione, 2015. Mappa Del Sistema Distributivo Italiano. (Available online at http://www.federdistribuzione.it/studi_e_ricerche.php).

Garrone, P., Melacini, M., Perego, A., 2014a. Opening the black box of food waste reduction. Food Policy 46, 129-139.

Garrone, P., Melacini, M., Perego, A., 2014b. Surplus food recovery and donation in Italy: the upstream process. Br. Food J. 116 (9), 1460-1477.

Gruber, V., Holweg, C., Teller, C., 2016. What a waste! exploring the human reality of food waste from the store manager's perspective. J. Public Policy Market. 35 (1), 3-25.

Gunders, D., 2012. Wasted: how america is losing up to 40 percent of its food from farm to fork to landfill. NRDC Issue Paper. (IP:12-06-B). https://www.nrdc.org/sites/ default/files/wasted-food-IP.pdf.

Gustavsson, J., Stage, J., 2011. Retail waste of horticultural products in Sweden Resources. Conserv. Recycl. 55 (5), 554-556.

Gustavsson, J., Cederberg, C., Sonesson, U., Van Otterdijk, R., Meybeck, A., 2011. Globa Food Losses and Food Waste: Extent, Causes and Prevention. FAO, Rome.

Hanssen, O.J., Møller, H., 2013. Food wastage in Norway 2013. Status Trends.

Ju, M., Osako, M., Harashina, S., 2017. Food loss rate in food supply chain using material flow analysis. Waste Manage. 61, 443-454.

Kummu, M., de Moel, H., Porkka, M., Siebert, S., Varis, O., Ward, P.J., 2012. Lost food, wasted resources: Global food supply chain losses and their impacts on freshwater, cropland, and fertiliser use. Science of the total environment 438, 477-489.

Lanfranchi, M., Giannetto, C., De Pascale, A., 2014. Analysis and models for the reduction of food waste in organized large-scale retail distribution in eastern Sicily. Am. J.
Appl. Sci. 11 (10), 1860

Lebersorger, S., Schneider, F., 2014. Food loss rates at the food retail, influencing factors and reasons as a basis for waste prevention measures. Waste Manage. 34 (11), 1911-1919.

Loebnitz, N., Schuitema, G., Grunert, K.G., 2015. Who buys oddly shaped food and why? Impacts of food shape abnormality and organic labeling on purchase intentions. Psychol. Market. 32 (4), 408-421.

Love, D.C., Fry, J.P., Milli, M.C., Neff, R.A., 2015. Wasted seafood in the United States: quantifying loss from production to consumption and moving toward solutions. Global Environ. Change 35, 116-124.

Mena, C., Adenso-Diaz, B., Yurt, O., 2011. The causes of food waste in the supplier-retailer interface: evidences from the UK and Spain. Resour. Conserv. Recycl. 55 (6), 648-658.

Papargyropoulou, E., Lozano, R., Steinberger, J.K., Wright, N., bin Ujang, Z., 2014. The food waste hierarchy as a framework for the management of food surplus and food waste. J. Clean. Prod. 76, 106-115.

Parfitt, J., Barthel, M., Macnaughton, S., 2010. Food waste within food supply chains: quantification and potential for change to 2050. Philos. Trans. R. Soc. London B: Biol. Sci. 365 (1554), 3065-3081.

Scherhaufer, S., Lebersorger, S., Pertl, A., Obersteiner, G., Schneider, F., Falasconi, L., De Menna, F., Vittuari, M., Hartikainen, H., Katajajuuri, J.M., Joensuu, K., Timonen, K., van der Sluis, A., Bos-Brouwers, H., Moates, G., Waldron, K., Mhlanga, N., Bucatariu, C.A., Lee, W.T.K., James, K., Easteal, S., 2015. Criteria for and Baseline Assessment of Environmental and Socio-Economic Impacts of Food Waste. (FUSIONS project).

Scholz, K., Eriksson, M., Strid, I., 2015. Carbon footprint of supermarket food waste. Resources. Conser. Recycl. 94, 56-65.

Segrè, A., Falasconi, L., Morganti, E., 2009. Last minute market. Increasing the economic, social and environmental value of unsold products in the food chain. In: Waldron, K.W., Moates, G.K., Faulds, C.B. (Eds.), Total Food: Sustainability of the Agri-Food Chain. RSC Publishing, UK.

Setti, M., Falasconi, L., Vittuari, M., Andrea, S., Cusano, I., 2016. Italian consumers' income and food waste behavior. Br. Food J. 118 (7).

Stenmarck, A., Jensen, C., Quested, T., Moates, G., 2016. Estimates of European Food Waste Levels. Publication of the FUSIONS Project. European Commission (FP7). Coordination and Support Action-CSA.

Stenmark, A., Hanssen, O.J., Silvennoinen, K., Katajajuuri, J.M., Werge, M., 2011. Initiatives on prevention of food waste in the retail and wholesale trades. TemaNord 548 (Copenhagen, Denmark).

Stuart, T., 2009. Waste - Uncovering the Global Food Scandal. Penguin Books, London.

Ziegler, G., Floros, J.D., 2011. A future perspective to mitigate food losses: the role of food science and technology. In: IFT 2011 Annual Meeting \& Food Expo. New Orleans, LA. . www.fmi.org, www.stopspildafmad.dk. 